MLM-2539

\title{
Volume Reduction System for Solid and Liquid TRU Waste from the Nuclear Fuel Cycle: April-June 1978
}

Barbara M. Alexander, Edward L. Lewis, Jay W. Doty and Dana H. Batchelder

July 25, 1978

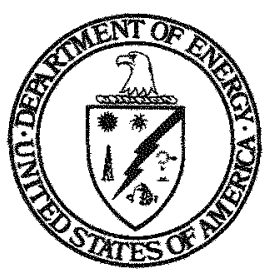

\section{MOUND FACILITY}

Miamisburg, Ohio

operated by

MONSANTO RESEARCH CORPORATION

a subsidiary of Monsanto Company

for the

U. S. DEPARTMENT OF ENERGY

Contract No. EY-76-C-04-0053 


\section{DISCLAIMER}

This report was prepared as an account of work sponsored by an agency of the United States Government. Neither the United States Government nor any agency Thereof, nor any of their employees, makes any warranty, express or implied, or assumes any legal liability or responsibility for the accuracy, completeness, or usefulness of any information, apparatus, product, or process disclosed, or represents that its use would not infringe privately owned rights. Reference herein to any specific commercial product, process, or service by trade name, trademark, manufacturer, or otherwise does not necessarily constitute or imply its endorsement, recommendation, or favoring by the United States Government or any agency thereof. The views and opinions of authors expressed herein do not necessarily state or reflect those of the United States Government or any agency thereof. 


\section{DISCLAIMER}

Portions of this document may be illegible in electronic image products. Images are produced from the best available original document. 
This report was prepared as an account of work sponsored by the United States Government. Neither the United States nor the United Staks Department of Energy, nor any of their employees, nor any of their contractors, subcontractors, or their employees, makes any warranty, express or implied, or assumes any legal

liability or responsibility for the accuracy, completeness or usefulness of any in-

formation, apparatus, product or process disclosed, or represents that its use

would not infringe privately owned rights.

\section{PRINTED IN THE UNITED STATES OF AMERICA}

Available from

National Technical Information Service

U. S. Department of Commerce 5285 Port Royal Road

Springfield, Virginia 22161

Price: Printed Copy $\$ 4.00$; Microfiche $\$ 3.00$ 
MLM-2539

UC -70

\section{Volume Reduction System for Solid and Liquid TRU Waste from the Nuclear Fuel Cycle: April-June 1978}

Barbara M. Alexander, Edward L. Lewis, Jay W. Doty and Dana H. Batchelder

Issued: July 25, 1978

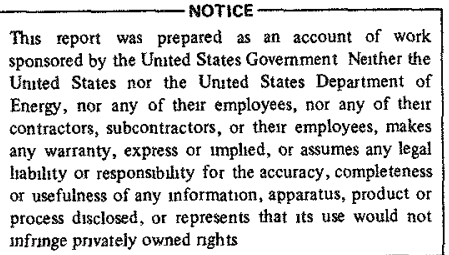

MOUND FACILITY

Miamisburg. Ohio 45342

operated by

MONSANTO RESEARCH CORPORATION

a subsidiary of Monsanto Company

for the

\section{U. S. DEPARTMENT OF ENERGY}

Contract No. EY-76-C-04-0053 


\section{Foreword}

Under the sponsorship of the DOE Division of Waste Management, Production and Reprocessing, Mound is responsible for the development of design critexia for a volume reduction system to treat combustible solid and liquid waste generated in the nuclear industry. Milestones for this project are shown on the following page.

This report is submitted by $W$. T. Cave, Director, Nuclear Operations, and B. R. Kokenge, Manager, Nuclear Technology, from contributions prepared by members of the Nuclear waste Technology section: K. V. Gilbert, Manager, The Volume Reduction Technology group: W. H. Bond, Leader, and the Waste Immobilization Group: J.W. Doty, Leader, and with the technical guidance of $\mathrm{J}$. W. Koenst.

Previous reports of this and the related project, TRU Waste Cyclone Drum Incinerator and Treatment System, are listed below:

Volume Reduction System for Solid and Liquid TRU Waste From the Nuclear Fuel Cycle:

$\begin{array}{ll}\text { April-June } 1977 & \text { MLM-2463 } \\ \text { July-September } 1977 & \text { MLM-2498 } \\ \text { October-December } 1977 & \text { MLM-2509 } \\ \text { January-March } 1978 & \text { MLM-2517 }\end{array}$

TRU Waste Cyclone Drum Incinerator and Treatment System:

$\begin{array}{ll}\text { April-June } 1977 & \text { MLM-2482 } \\ \text { July-September } 1977 & \text { MLM-2496 } \\ \text { October-December } 1977 & \text { MLM-2510 } \\ \text { January-March } 1978 & \text { MLM-2516 }\end{array}$


MILESTONE CHART

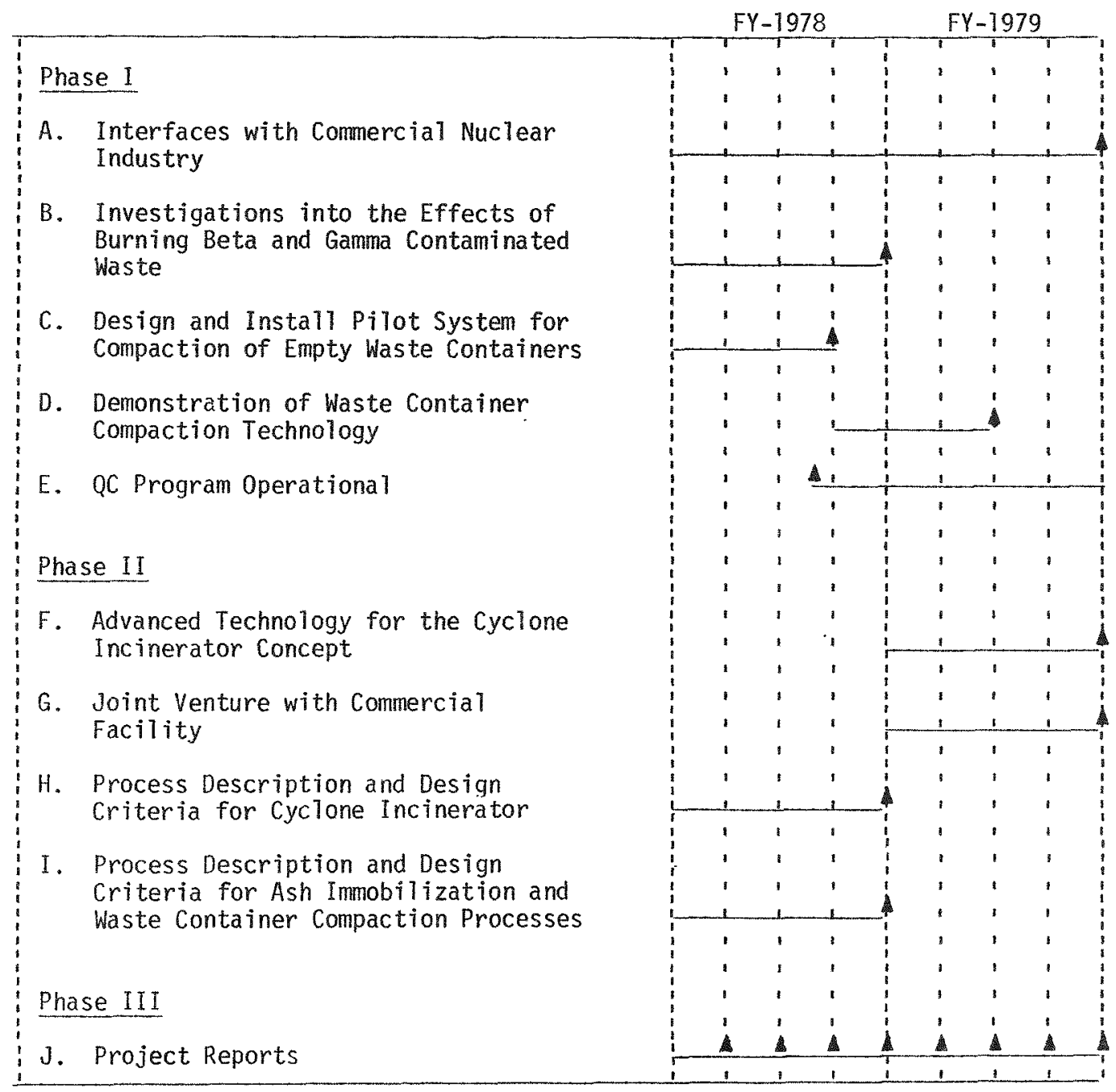




\section{Contents}

$\underline{\text { Page }}$

ABSTRACT . . . . . . . . . . . . . . . . . . . . . 5

MILESTONE B: EFFECTS OF BURNING BETA AND GAMMA CONTAMINATED WASTES. . . . . 5

Bench-Scale Incinerator . . . . . . . . . . . . . . 5

MILESTONE E: QUALITY CONTROL. . . . . . . . . . . . . . . . . 10

MILESTONE F: DRUM COMPACTION. . . . . . . . . . . . . . . . 10

WASTE IMMOBILIZATION

Introduction. . . . . . . . . . . . . . . . . . . 13

Pressed Ash-Cement Pellet Experiments . . . . . . . . . . . . . 13

Sintering of Experimental Incinerator Ash . . . . . . . . . . 15

DISTRIBUTION . . . . . . . . . . . . . . . . . . 18 


\section{Abstract}

The laboratory cyclone incinerator has been developed to study the effects of burning feed containing radionuclides other than plutonium-238. These isotopes, which will be primarily products of fission, must be efficiently removed from the off-gas if combustible waste containing such species is to be incinerated.

Modifications to the original incinerator design were made to increase the efficiency of combustion and particulate removal in the system and to reduce its energy consumpution.

A drum compactor was purchased, installed, and tested. The test results were as expected; a 55-gal steel drum volume was reduced by $86 \%$.

The ash/cement matrix studies were completed. The $65 / 35$ mixture proved to be the best for dry-cure pellets, and the $80 / 20$ mixture produced the best wet-cured pellets. Experimental incinerator ash was successfully sintered; the final carbon content was less than 0.1 wto.

\section{Milestone B: Effects of burning beta and gamma contaminated wastes}

\section{B. M. Alexander}

Since the inception of the commercial incinerator project, a major concern has been the identification and removal from the off-gas of radioactive gases and particles different from those encountered in burning plutonium-contaminated wastes.

This problem is being studied experimental$1 y$ with a laboratory-scale incinerator to develop new technology which will expand the application of cyclone incinerator technology in the commercial nuclear industry. This incinerator system is approximately $1 / 9$ the size of the Cyclone Incinerator.

\section{Bench-scale incinerator}

The purpose of the laboratory cyclone incinerator project is to study the effects of burning wastes contaminated with isotopes other than plutonium-238 in a cyclone system. The original laboratory incinerator (Figures 1 and 2) included an off-gas treatment system for the removal of chlorides and particulate matter. This system consisted of a deluge tank using a caustic scrubbing solution and two stages of filtration. In the initial stages of the experimental program, optimizing combustion efficiency and particulate removal of the system was emphasized. After this, the feed will be doped with various elements of interest, such as fission products, which are found in commercial wastes. The removal efficiency of the system for each element will be 


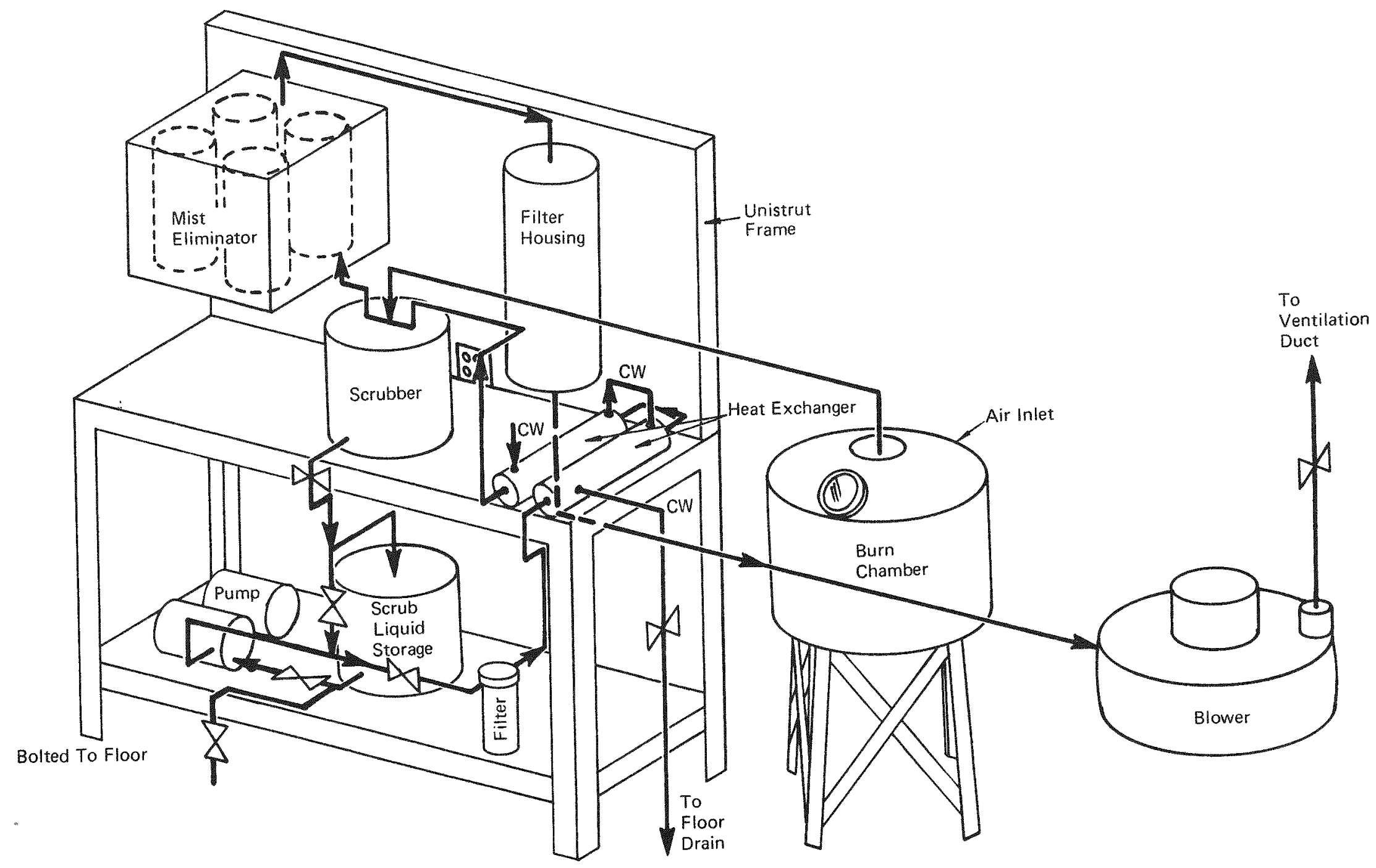

FIGURE 1 - Schematic of original laboratory-scale incinerator. 


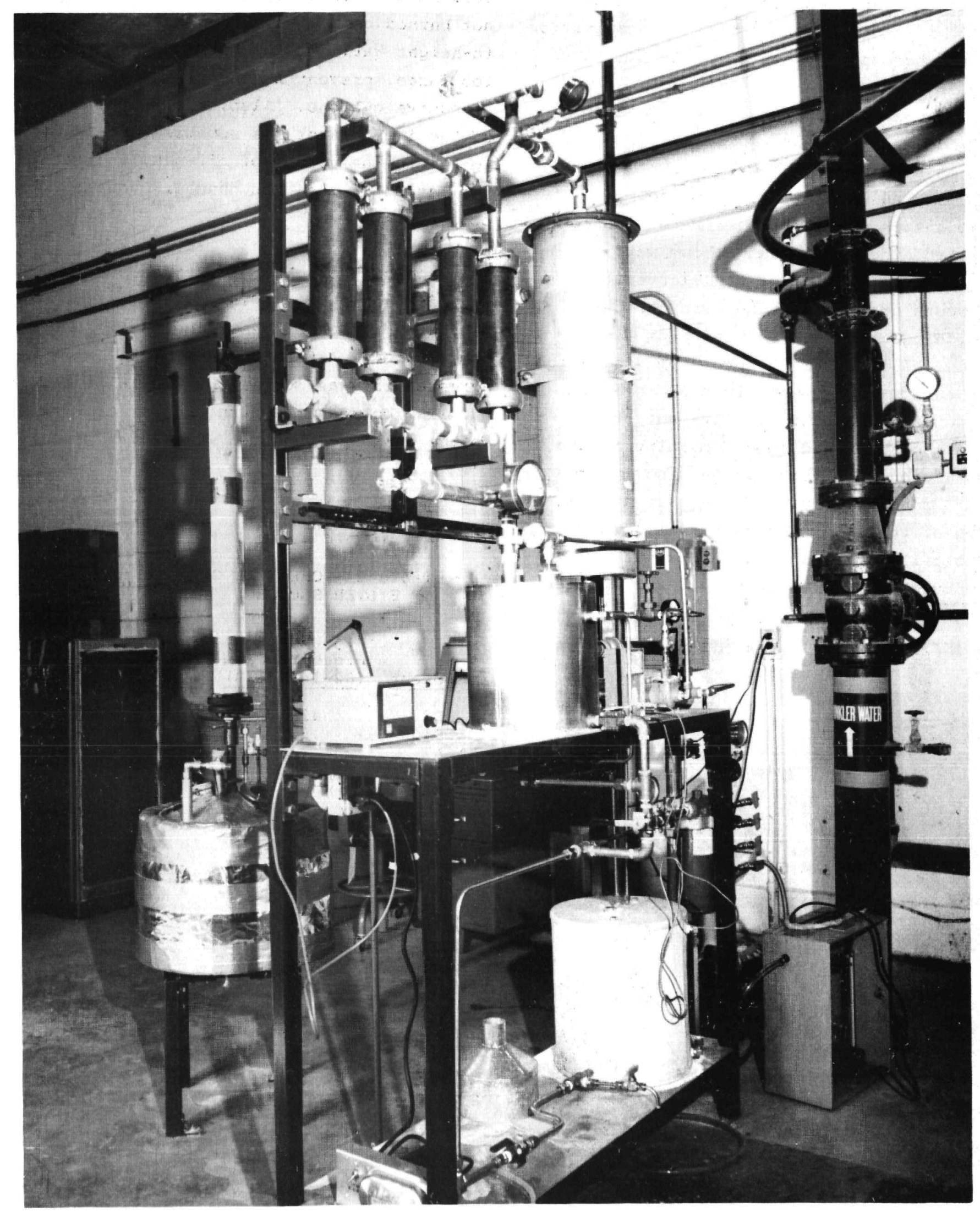

FIGURE 2 - Overall view of original laboratory-scale cyclone incinerator. 
determined and necessary modifications will be made to improve the decontamination factor across the system for each isotope.

In early March, the incinerator system was modified to reduce pressure drop and increase airflow through the system. Half the packing was removed from the mist eliminators, process lines were cleaned out, and the valves and elbows were removed from the air inlets (Figure 3). Pressure drop across the burn chamber and deluge tank was reduced from 41 to 30 in. of water, while pressure drop across the entire system went from 68 to 56 in. of water. With this improvement, the amount of unburned feed remaining in the combustion chamber after burning was reduced considerably, and the carbon content of the sludge produced was lower (Table 1). The maximum temperature in the burn chamber reached $1500^{\circ} \mathrm{F}$. However,

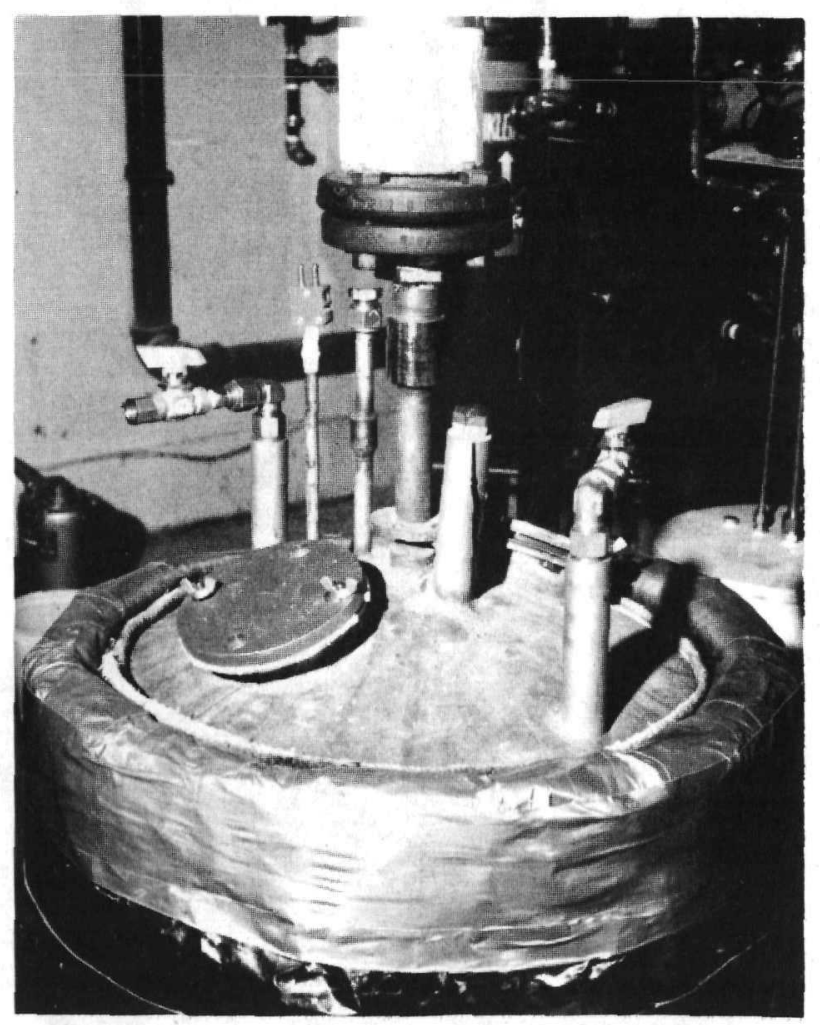

FIGURE 3 - Original combustion chamber before removal of valves and elbows from air inlets. feed in the center of the chamber was still not burned completely because the widthto-height ratio of the burning chamber was too large, preventing the formation of an effective cyclone. Also, the off-gas line of the incinerator was sometimes inadequate to handle the volume of off-gas, and pressurization of the burn chamber occasionally occurred.

A new combustion chamber with a lower heightto-width ratio was designed, similar to one used with the experimental Mound Cyclone Incinerator. A 6-gal drum with a flamearrester lid was modified. The l-in. offgas line between the burn chamber and the deluge tank was replaced with 2 -in. pipe.

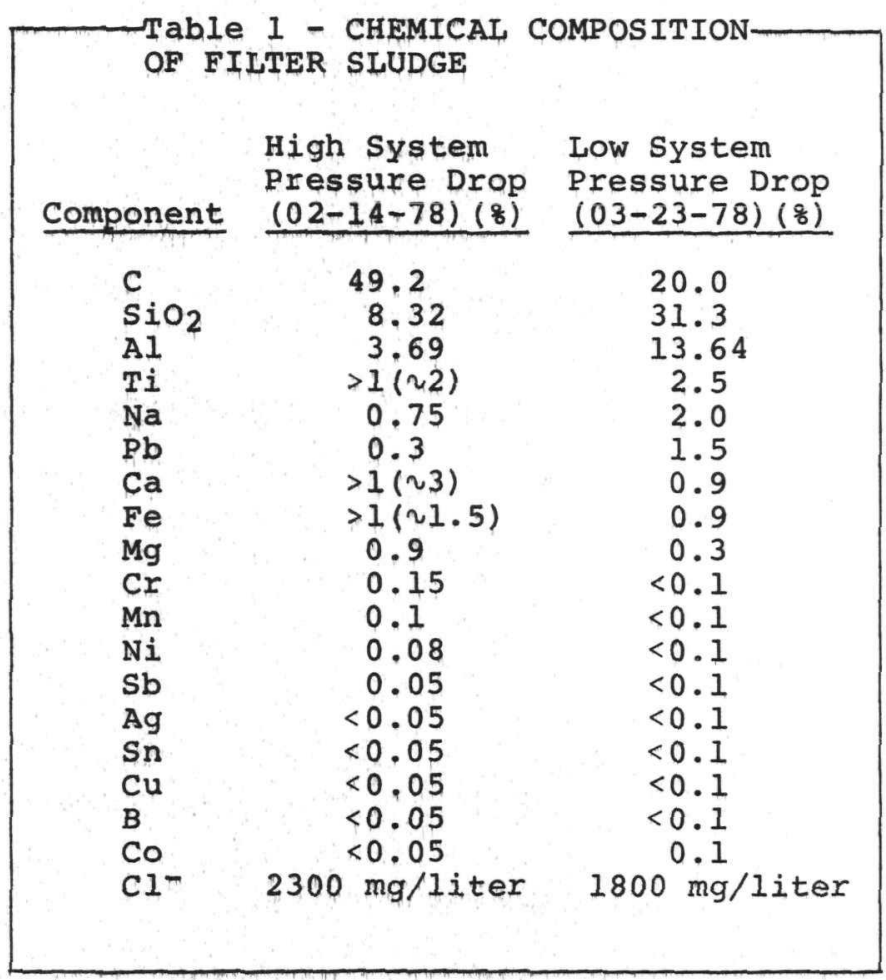


The major problem with the new combustion chamber has been achieving an airtight seal between the combustion chamber and its 1id. Acceptable results have been obtained by using twisted asbestos rope, but a more flexible replacement material is desired. Also, a high rate of particle carryover from the burn chamber has occurred, especially when the chamber is ful1, because of the decreased pressure drop (17 in. of water across the chamber, 49 in. of water across the system) and increased airflow through the chamber. Carryover has been reduced considerably by installing a fine screen just above the combustion chamber in the off-gas line.

The high carryover is evident from the low weight reduction calculated for the 17 runs made in the new incinerator. The ratio of feed weight to the weight of ash and sludge averaged 5:1. Excess moisture in the sludge may contribute to this low weight-reduction value.

Eleven runs were made in the first 6-gal drum before it was discarded. At the end of 11 temperature cycles, the sides of the drum were dented and rusty (Figure 5), but there were no holes or cracks in it, although it was made only of very thin sheet metal. The swirling aix flow, which cools the arum sides, probably caused this long life.

The fission product that is expected to pose the greatest problem in the off-gas is ruthenium. From 1iterature research, ruthenium is found to react in air at temperatures over $1650^{\circ} \mathrm{F}$ to form a volatile compound, which decomposes below $1200^{\circ} \mathrm{F}$ to form an insoluble deposit.

To handle this element, a fluidized bed spray scrubber has been designed to replace the existing deluge tank and mist eliminators. This spray scrubber will have two fluidized stages of 6-mm glass beads. A fluidized bed design was chosen because its turbulence will cause more intimate contact between the off-gas and the scrub liquor and will dislodge any deposited ruthenium from the bed. A strong reducing agent, probably sodium hypophosphite, will be added to the caustic scrub liquor, because it effectively reduces the volatile form of ruthenium to a nonvolatile form. A mist eliminator is incorporated in the top of the scrubber to remove entrained aroplets from the off-gas. The spray scrubber is now being fabricated and should be installed by the midale of July. Figure 6 is a flow diagram of the modified laboratory-scale incinerator, including the new spray scrubber.

Incinerator feed will be spiked with stable isotopes of elements such as cesium, cerium, cobalt, and ruthenium, which are common fission products, by dissolving them in water and mixing the solution with incinerator feed material. Samples of the off-gas, as well as samples of ash, sludge, and scrub liquor, will be analyzed to determine where the bulk of each element is removed. These experiments will begin at the end. of June. 


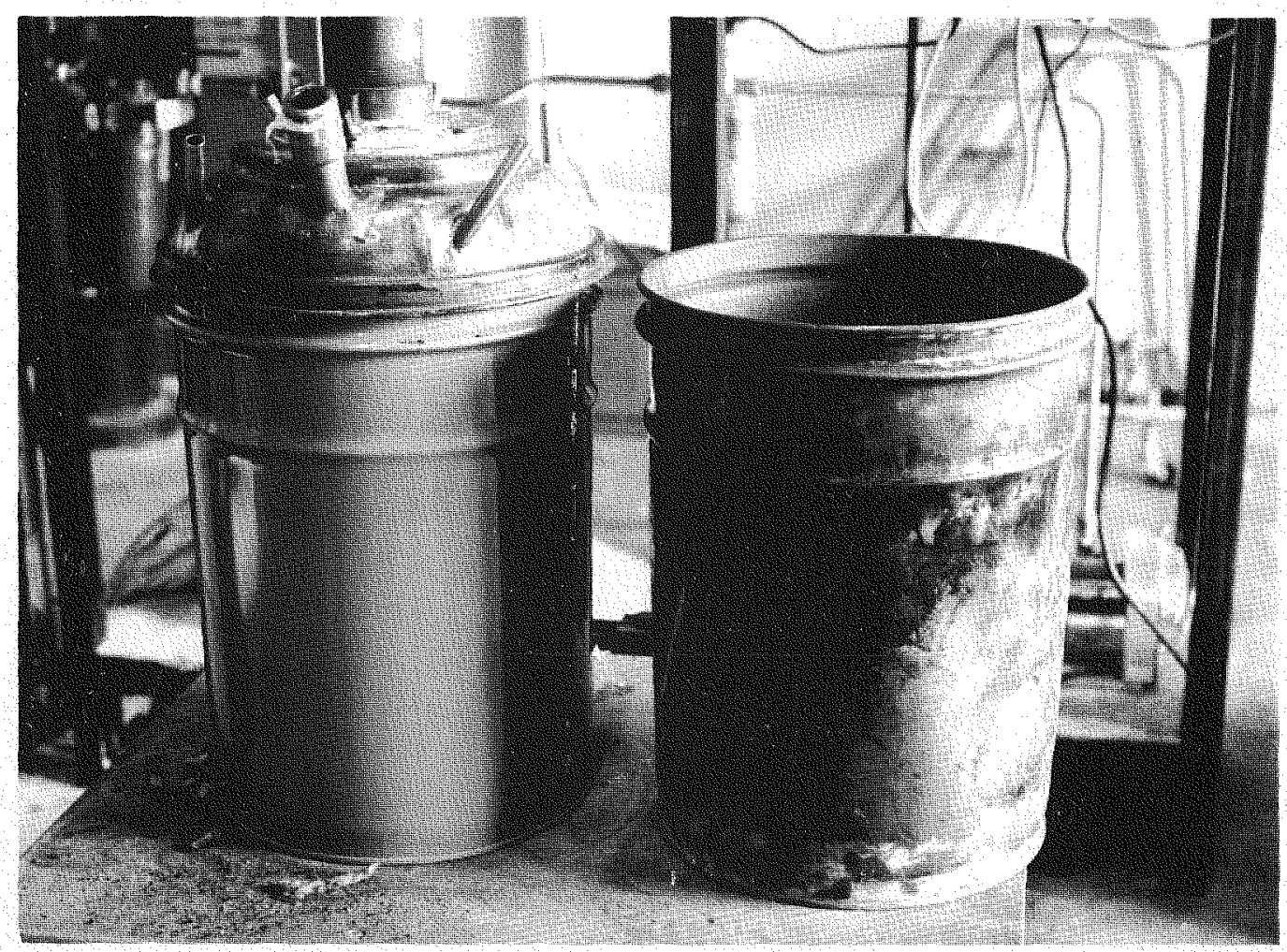

FIGURE 5 - New 6-gal drum (left), next to drum in which 11 burns were made (right).

\section{Milestone E: Quality Control}

A quality control program for the DWMfunded development project, "Volume Reduction system for Solid and Liquid TRU Waste from the Nuclear Fuel Cycle" was started this quarter. The objective of this program is to generate reliable, traceable data. Because the developed technology is to be used in a full-scale operating system, the data must be valid. The basis for the quality control program are process flow diagrams which identify the specific control mechanisms used to validate the data generated. These diagrams provide an easy way to check our quality control program during its development and to implement a more specific quality control program. A quality control organization is presently operational at Mound, but it has not previously scrutinized research and development projects.
The triangles on the flow diagram (Figure 6) identify the areas where quality control methods are used in the new procedures.

\section{Milestone C: Drum Compaction}

\author{
E. L. Lewis
}

Preliminary testing of the Model 55-AR drum compacting unit was completed in May 1978 (see Figures 7 and 8). The drum compactor is manufactured by $\mathrm{S} \& \mathrm{G}$ Enterprises (Ram Trademark). The unit performed well and no mechanical problems were encountered. The compacting ratio (initial volume divided by final volume) was approximately as expected for the various items compacted. Table 2 lists the ratios and other information 


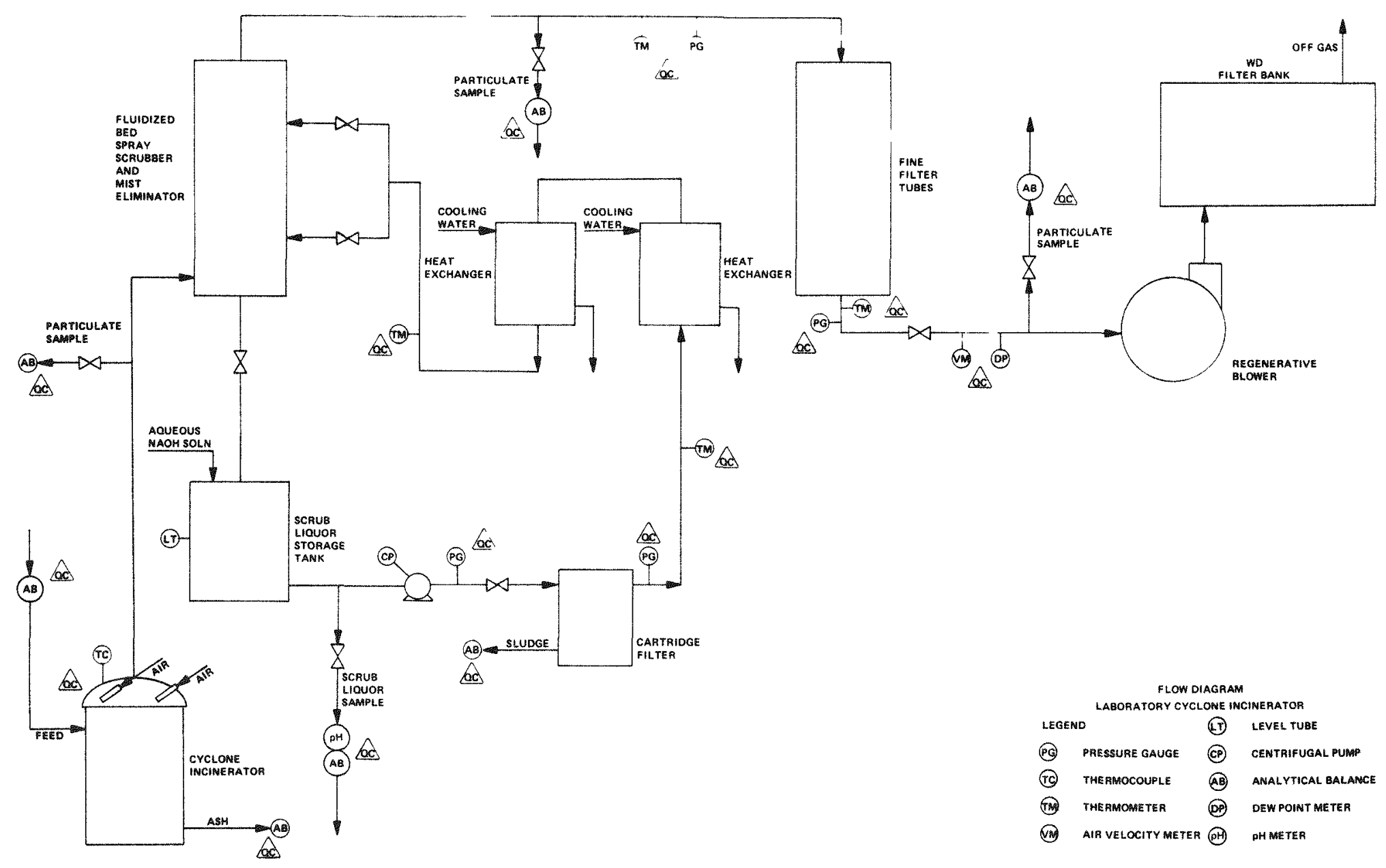

FIGURE 6 - Updated flow diagram for the laboratory-scale cyclone incinerator. 


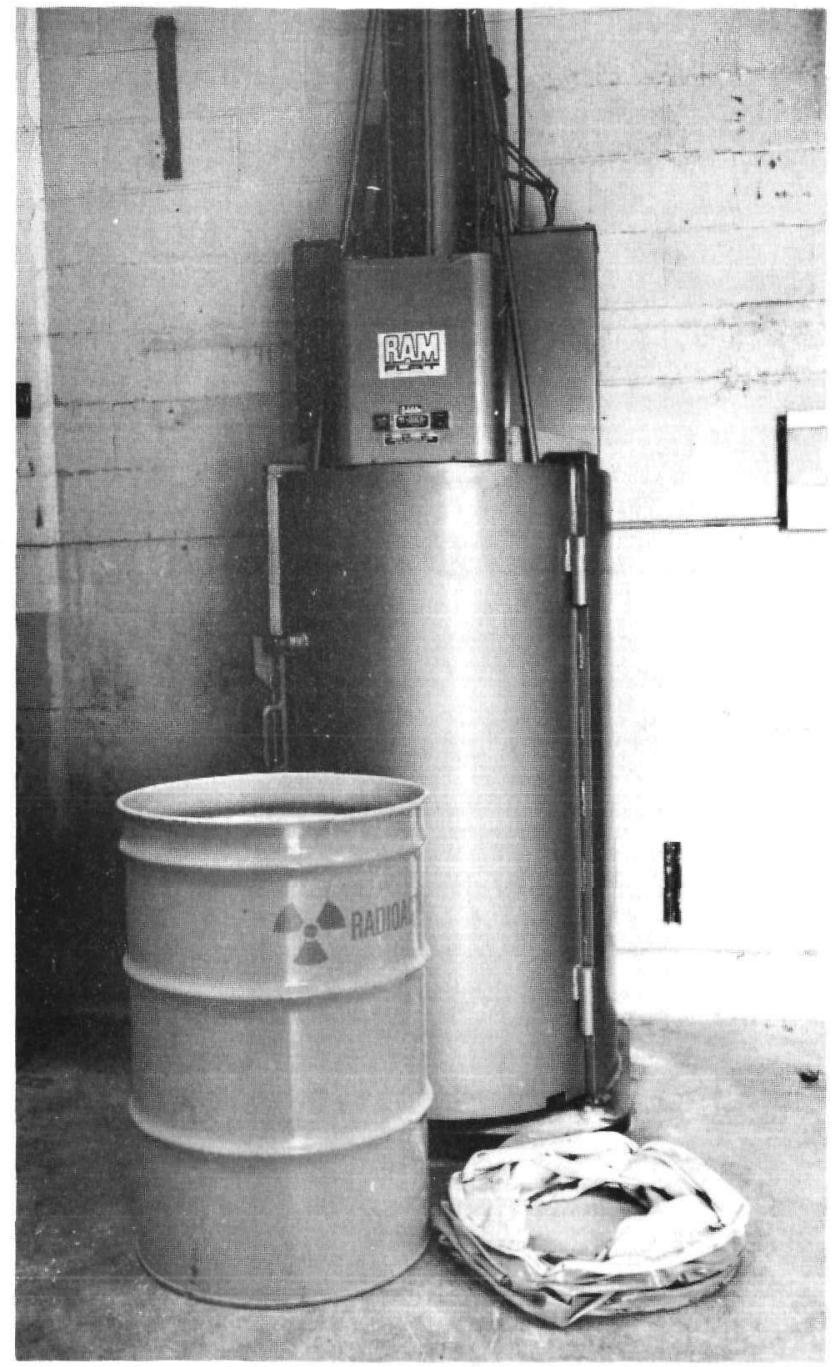

FIGURE 7 - Compaction of 55-gal steel drum.

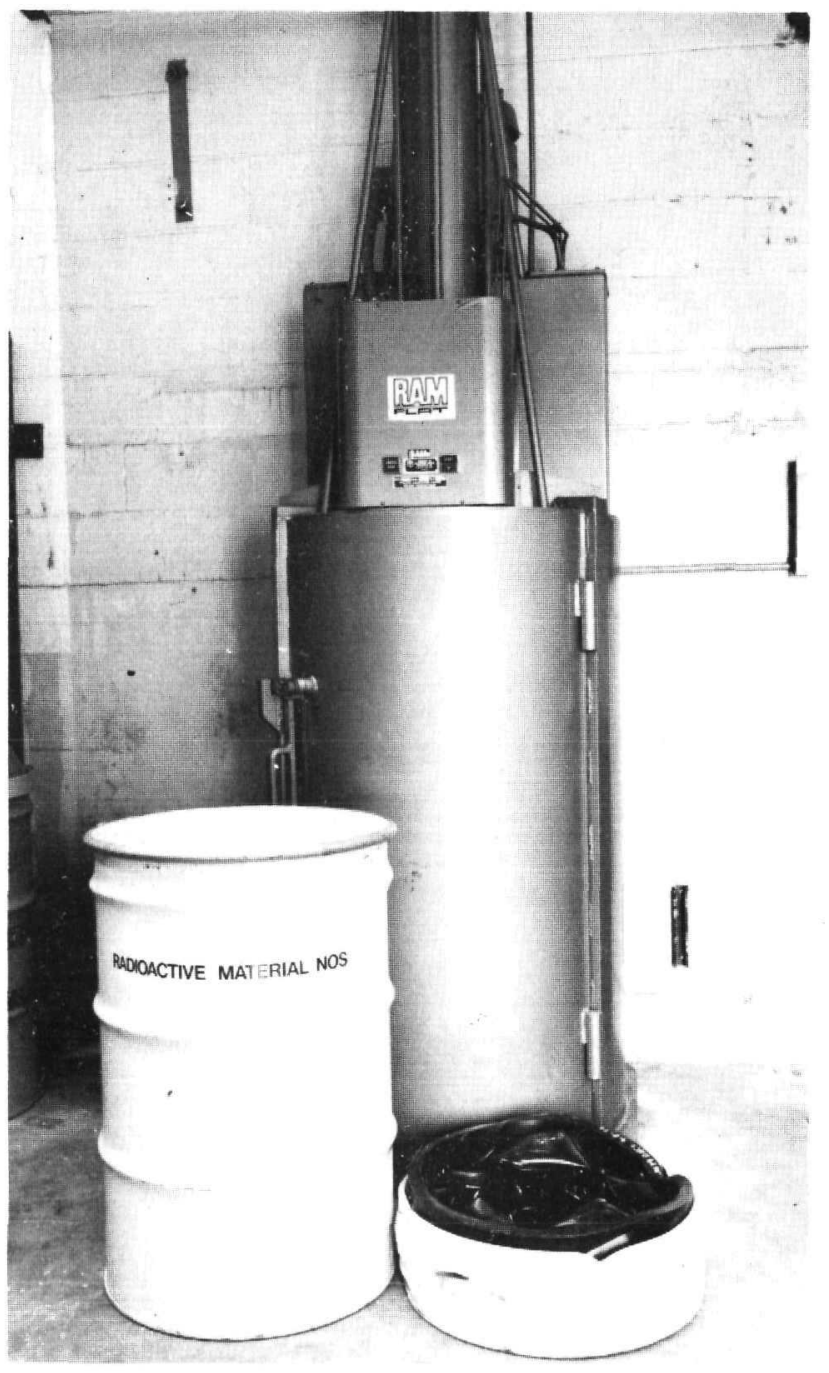

FIGURE 8 - Compaction of 55-gal steel drum with TRU liner.

Table 2 - PRELIMINARY TESTING OF DRUM COMPACTOR

\begin{tabular}{|c|c|c|c|}
\hline & $\begin{array}{l}\text { Initial } \\
\text { Volume } \\
\text { (ft } \mathrm{ft}^{3} \\
\end{array}$ & $\begin{array}{l}\text { Final } \\
\text { Volume } \\
\left(\mathrm{ft} \mathrm{t}^{3}\right)\end{array}$ & $\begin{array}{c}\text { Compacting } \\
\text { Ratio }\end{array}$ \\
\hline 55-gal Steel Drum & 8.65 & 1.20 & 7.21 \\
\hline $\begin{array}{l}\text { 55-gal Steel Drum } \\
\text { with TRU Liner }\end{array}$ & 8.65 & 2.71 & 3.19 \\
\hline $\begin{array}{l}\text { 55-gal Drum with } \\
\text { 30-gal Drum Inside }\end{array}$ & 8.65 & 2.92 & 2.96 \\
\hline
\end{tabular}


for these items. Additional drums will be compacted in order to further demonstrate the compactor.

\section{Waste Immobilization}

J. W. Doty, D. H. Batchelder and E. L. Lewis

\section{Introduction}

The objectives of this task are to evaluate various TRU waste immobilization methods and compare these against existing and newly developed waste form acceptance criteria. Also, this program has as its objective the immobilization of sludges. adsorbents, incinerator ash, and salts. This section is funded by the Defense waste program but is included here for completeness.

\section{Pressed ash-cement pellet experiments}

Additional experiments were done in order to evaluate and select the best pellet matrix for incinerator ash and Portland IA cement. Pellets of 1/2-in. diameter were pressed with the following parameters held constant:

1. Fabrication pressure of 25,000 psi for I-min duration

2. Three-gram pellet weight

3. Dry cure cycle - a minimum of two days ( $48 \mathrm{hr}$ ) in open atmosphere

4. Wet cure - a minimum of four days (96 hr) cure in distilled water followed by a one-day cure in open atmosphere

Four groups of waste samples were evaluated during this period. pellets were pressed with Type I, II, III, and UK (unknown) ash. The water-to-cement ratio was varied in in each sample group to determine the most acceptable composition. Normally, four water-to-cement ratios were evaluated ranging from a too-dry condition to a too-moist condition. Table 3 contains data for the $65 \%$ ash pellets as well as $0,60,70$, and $80 \%$ ash pellets completed last quarter. The data for the $65 \%$ ash/35\% cement are given for only the best water-to-cement ratio.

Once again, the wet-cured pellets exhibited higher crush strengths over the dry-cured pellets. The 65\% dry-cured ash pellets produced acceptable crush strengths for Type I, II, and III ash. The $70 \%$ and $80 \%$ ash/cement pellets, dry cured, were unacceptable because of low crush strengths. Therefore, the $65 / 35$ matrix appears to be the best for dry-cured pellets. When considering crush strengths and percent ash for wet-cured pellets, the $80 / 20$ matrix appears to be the best. The $65 / 35$ pellets containing 3 wto sodium metasilicate $\left(\mathrm{Na}_{2} \mathrm{SiO}_{3}\right)$ binder had approximately the same crush strengths as those without. Additional pellets containing 10 wto sodium metasilicate were fabricated in an attempt to produce pellets having higher crush strengths. Test results are not yet available.

Table 4 contains free moisture data for pellets of different mixture ratios and ash type. When pellets of identical composition were compared, the wet-cured pellets had more free moisture than the drycured pellets. This was as expected.

Table 5 lists bulk and tap density measurements of various ash types and bone char. These measurements were made so that the fill depths of the 1/2-in. diameter die sets could be determined. There was a wide variation in bulk density, from a minimum of $0.29 \mathrm{~g} / \mathrm{cm}^{3}$ to a maximum of $0.91 \mathrm{~g} / \mathrm{cm}^{3}$. 
Table 3 - PRESSED ASH-CEMENT PELLET MATRIX CONTROLLED EXPERIMENTAL PROCESS

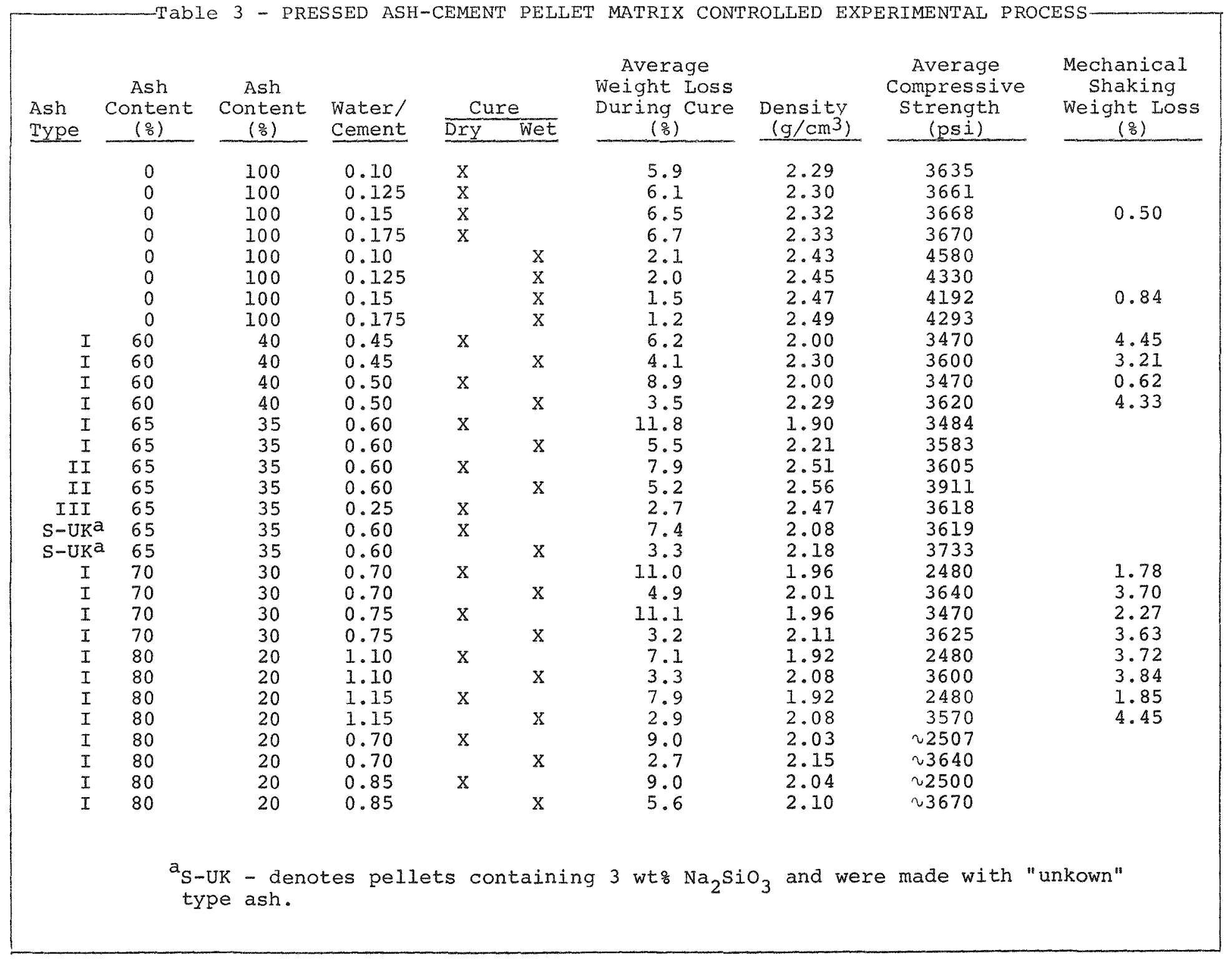


Table 4 - FREE MOISTURE IN PELLETS

\begin{tabular}{|c|c|c|c|c|c|}
\hline \multirow{2}{*}{$\begin{array}{l}\text { Ash } \\
\text { Type }\end{array}$} & \multirow{2}{*}{$\begin{array}{l}\text { Mixture } \\
\text { Ratio } \\
\end{array}$} & \multirow{2}{*}{$\begin{array}{l}\text { Water } / \\
\text { Cernent }\end{array}$} & \multirow{2}{*}{$\begin{array}{c}\text { Free } \\
\text { Moisture } \\
\left(\frac{0}{6}\right) \\
\end{array}$} & \multicolumn{2}{|c|}{ Cure } \\
\hline & & & & $\overline{\mathrm{Dry}}$ & Wet \\
\hline I & $60 / 40$ & 0.45 & 1.2 & & $\mathrm{x}$ \\
\hline I & $60 / 40$ & 0.45 & 0.78 & $\mathrm{x}$ & \\
\hline I & $60 / 40$ & 0.50 & 0.76 & & $x$ \\
\hline I & $60 / 40$ & 0.50 & 0.50 & $x$ & \\
\hline I & $70 / 30$ & 0.70 & 0.95 & & $\mathrm{x}$ \\
\hline$I$ & $70 / 30$ & 0.70 & 0.22 & $\mathrm{x}$ & \\
\hline I & $70 / 30$ & 0.75 & 0.89 & & $x$ \\
\hline I & $70 / 30$ & 0.75 & 0.37 & $x$ & \\
\hline I & $80 / 20$ & 1.10 & 1.2 & & $\mathrm{x}$ \\
\hline I & $80 / 20$ & 1.10 & 0.22 & $\mathrm{x}$ & \\
\hline I & $80 / 20$ & 1.15 & 0.80 & & $\mathrm{x}$ \\
\hline I & $80 / 20$ & 1.15 & 0.28 & $\mathrm{x}$ & \\
\hline
\end{tabular}

Thermal-gravimetric analysis (TGA) of crushed ash-cment pellets was completed but the results are not yet available. The reason for the analysis is to determine how much water vapor and other gases are given off at various temperatures.

An analysis is being done by the Experimental Design Group to find the optimum ash-cement matrix and to suggest further experiments necessary for the determination.

\section{Sintering of experimental incinerator ash}

Sintering experiments were performed using experimental incinerator ash containg 10-50 wt: carbon plus other incompletely burned material. The ash must therefore be sintered or burned again to remove this combustible material. Table 6 contains data from four experimental sintering tests.
Table 5 - BULK AND TAP DENSITY MEASUREMENTS

Ash Bulk Density Tap Density

Type $-\left(\mathrm{g} / \mathrm{cm}^{3}\right)-\left(\mathrm{g} / \mathrm{cm}^{3}\right)$

$\begin{array}{lll}I & 0.53 & 0.80\end{array}$

$\begin{array}{lll}I I & 0.80 & 1.25\end{array}$

III $\quad 0.61 \quad 1.02$

$\begin{array}{lll}\mathrm{UK}-1^{\mathrm{a}} & 0.34 & 0.45\end{array}$

$\begin{array}{lll}\mathrm{UK}-2^{\mathrm{a}} & 0.29 & 0.41\end{array}$

$\begin{array}{lll}\mathrm{UK}-3^{\mathrm{a}} & 0.36 & 0.60\end{array}$

$\begin{array}{lll}\mathrm{CSBC}^{\mathrm{b}} & 0.91 & 1.21\end{array}$

a UK is an abbreviation for "unknown"

${ }^{b}$ CSBC is an abbreviation for "crushed, sintered bone char 


\begin{tabular}{|c|c|c|c|c|c|c|}
\hline Run & $\begin{array}{c}\text { Combustion } \\
\text { Rate } \\
\left(\mathrm{g} / \mathrm{cm}^{3}\right) \\
\end{array}$ & $\begin{array}{c}\text { Sintered } \\
(\mathrm{hr} r) \\
\end{array}$ & $\begin{array}{l}\text { Temperature } \\
\quad\left({ }^{\circ} \mathrm{C}\right) \\
\end{array}$ & $\begin{array}{c}\text { Initial } \\
\text { Weight } \\
\text { (\% Carbon) }\end{array}$ & $\begin{array}{c}\text { Final } \\
\text { Weight } \\
\text { (\% Carbon) } \\
\end{array}$ & $\begin{array}{l}\text { Ratio } \\
\text { Carbon Wt Loss } \\
\text { to Total Wt Loss }\end{array}$ \\
\hline 1 & 5.7 & $6-1 / 2$ & $800-900$ & 12.82 & 0.005 & 0.46 \\
\hline 2 & 5.8 & $10-3 / 4$ & 850 & 46.3 & $<0.10$ & 0.95 \\
\hline 3 & 1.7 & 8 & 900 & 48.7 & $<0.05$ & 0.88 \\
\hline 4 & 1.6 & 8 & 850 & 48.7 & $<0.005$ & 0.92 \\
\hline
\end{tabular}

The purpose of these experiments was to develop an acceptable sintering process. This process must reduce the carbon content to less than $0.10 \%$ at a fairly rapid rate. Runs \#1 and \#2 were the most successful of the four tests. The final carbon percentages and combustion rates were almost identical for these runs. Runs \#3 and \#4 produced ashes of acceptable carbon contents but the combustion rates were approximately $3 / 10$ of those found in Runs \#1 and \#2. In Runs \#1 and \#2, the ash was sintered in a cylindrical quartz vessel containing a quartz frit (see

Figure 9). The ash was placed on the frit, and air was either pulled downward through the frit or pumped upward through the frit. The aix flow rate was approximately $3.5 \mathrm{ft}^{3} /$ hr. In Runs \#3 and \#4, the ash was sintered in a shallow quartz dish with air flowing above the surface of the dish at a rate of approximately $3.5 \mathrm{ft}^{3} / \mathrm{hr}$. The greater combustion rates for Runs 1 and \#2 were probably attained by better contact between the combustion air and the heated dish. Some problems were, however, encountered in the use of the fritted vessel. The quartz frit partially plugged after $8 \mathrm{hr}$ of use. Both the quartz side arm (air inlet-outlet tube) and vessel wall both broke during the second run. No problems were encountered in the use of the quartz dish. The problems encountered with the quartz vessel may possible be corrected by fabricating a platinum vessel. Figure 10 is a plot of percent carbon remaining in ash as a function of sintering time for Run \#2. As can be seen, it is nearly linear between time zero and $7-3 / 4$ hr and nonlinear between $7-3 / 4 \mathrm{hr}$ and $10-3 / 4 \mathrm{hr}$. AIl four runs were conducted using a muffle furnace and a temperature range of $800-900^{\circ} \mathrm{C}$. Analytical tests are now being performed to determine the composition of the combustion gases produced at various temperatures $\left(200\right.$ to $\left.900^{\circ} \mathrm{C}\right)$. These test results are not yet available. 


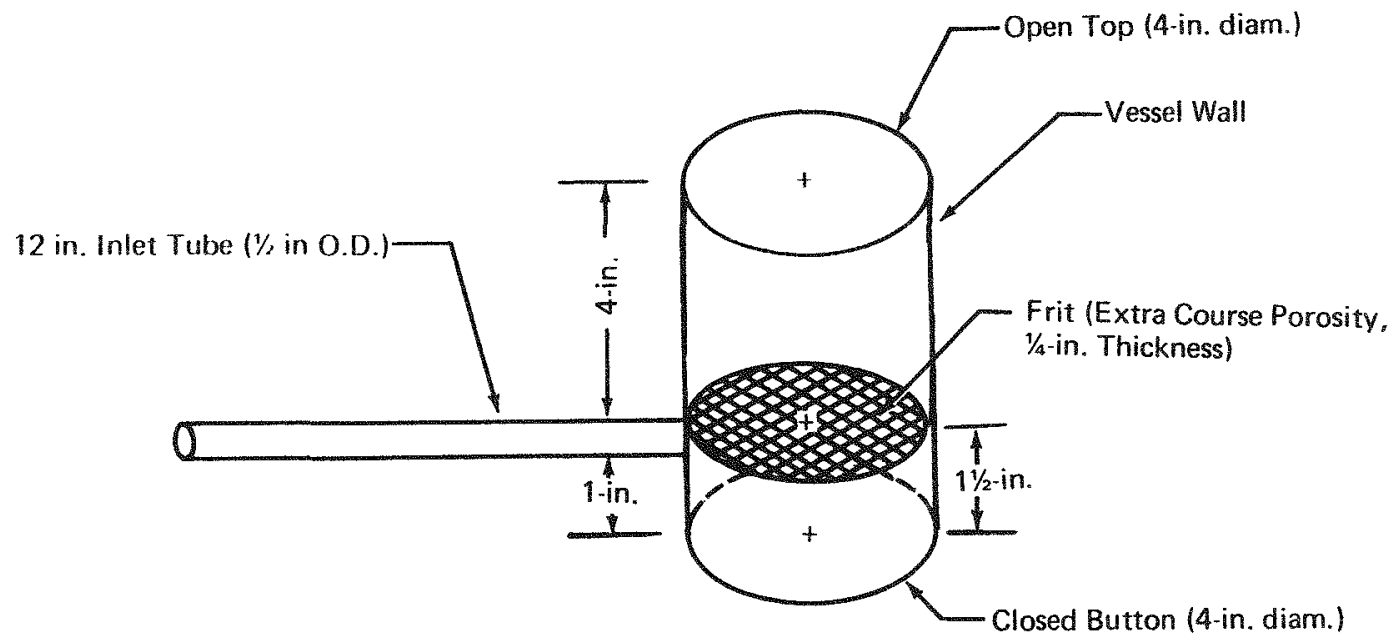

FIGURE 9 - Cylindrical quartz sintering vessel.

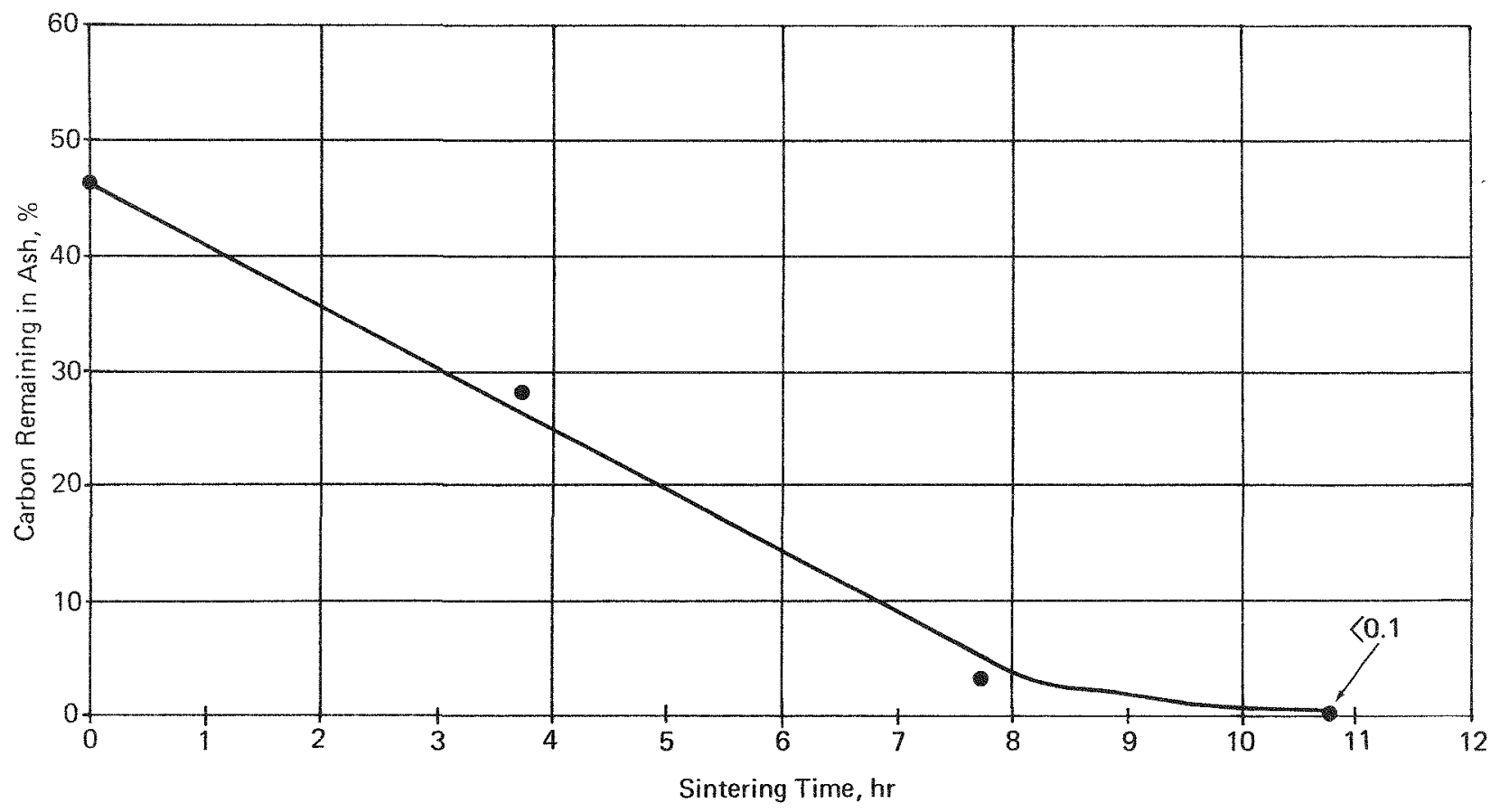

FIGURE 10 - Percent carbon in ash as a function of sintering time. 


\title{
Distribution
}

\author{
EXTERNAI
}

TIC, UC-70 (267)

H. N Hi1l, DOE, Dayton Area Office (2)

T. C. Chee, DOE, Division of Waste Management

T. C. Jones, DOE, Albuquerque Operations office

R. Y. Lowrey, DOE, Albuquerque Operations office

D. W. King, DOE, Albuquerque Operations office

T. K. Keenan, Los Alamos Scientific Laboratory

J. O. Blomeke, Oak Ridge National Laboratory

J. A. Leary, DOE, Waste Process and Recovery

R. E. Lerch, Hanford Engineering Development Laboratory

R. K. Flitcraft, Monsanto Research Corporation

G. Oertel, DOE, Division of Waste Management

R. D. Walton, Jr., DOE, Division of Waste Management

\section{INTERNAI}

B. M. Alexander

W. R. Amos

A. G. Barnett

B. E. Baughn

W. H. Bond

W. T. Cave

J.W. Doty

T. C. Elswick

K. V. Gilbert

R. C. Herman

C. W. Huntington

L. V. Jones

L. M. Klingler

J.W. Koenst (3)

B. R. Kokenge

E. L. Lewis

J. R. MCClain

D. I. Prosser

L. B. Stevens

J. E. Todd

R. E. Vallee

Library (10)

Publications 